\title{
Adult attention deficit hyperactivity disorder is associated with asthma
}

Ole Bernt Fasmer ${ }^{1,2,3^{*}}$, Anne Halmøy ${ }^{2,3,4}$, Tomas Mikal Eagan ${ }^{5,6}$, Ketil Joachim Oedegaard ${ }^{1,2,3}$ and Jan Haavik 2,3,4

\begin{abstract}
Background: Attention deficit hyperactivity disorder (ADHD) is increasingly recognized as a common disorder not only in children, but also in the adult population. Similarly, asthma also has a substantial prevalence among adults. Previous studies concerning a potential relationship between ADHD and asthma have not presented consistent results.

Methods: A cross-sectional study of 594 adult patients diagnosed with ADHD, compared with 719 persons from the general population. Information was collected between 1997 and 2005 using auto-questionnaires rating past and present symptoms of ADHD, co-morbid conditions, including asthma, and work status.

Results: The prevalence of asthma was significantly higher in the ADHD patient group compared to the controls, $24.4 \%$ vs. $11.3 \%$ respectively ( $O R=2.54,95 \% \mathrm{Cl} 1.89-3.44)$, and controls with asthma scored higher on ratings of both past and present symptoms of ADHD. Female ADHD patients had a significantly higher prevalence of asthma compared to male ADHD patients (30.9\% vs. 18.2\%, OR = 2.01, Cl 1.36-2.95), but in controls a slight female preponderance was not statistically significant. In both ADHD patients and controls, having asthma was associated with an increased prevalence of symptoms of mood- and anxiety disorders.
\end{abstract}

Conclusions: The present findings point to a co-morbidity of ADHD and asthma, and these patients may represent a clinical and biological subgroup of adult patients with ADHD.

\section{Background}

Attention deficit hyperactivity disorder (ADHD) is a common disorder in children causing substantial problems for those afflicted [1-3]. During the last 10-15 years ADHD has been the focus of increasing interest also in adult psychiatry [2-4]. The prevalence of ADHD is estimated to be in the range of $2-12 \%$ in children [5-7] and 3-5\% in adults [8,9]. Many children with ADHD retain impairing symptoms as adults, causing difficulties in relation to educational, social and occupational functioning $[10,11]$. In addition, ADHD is associated with many other psychiatric disorders, in particular anxiety- and mood disorders $[9,11]$.

Like ADHD asthma is also perceived as a disease of childhood, however with a significant adult prevalence and incidence [12-14]. Both asthma [15] and ADHD [16] have a clear genetic component. Asthma has a well

\footnotetext{
* Correspondence: ole.fasmer@kliniskmedisin.uib.no

'Department of Clinical Medicine, Section for Psychiatry, University of Bergen, Bergen, Norway

Full list of author information is available at the end of the article
}

established co-morbid connection with psychiatric disorders. Children with asthma have a higher prevalence of behavioural difficulties than children without asthma [17]. Among adult asthmatics, there is a higher prevalence of depression and anxiety disorders than in the general population [18-20].

The pathophysiology and genetics of ADHD probably involve multiple neurotransmitter systems, including dopaminergic mechanisms [21], but a comprehensive understanding of this disorder is still lacking. Pelsser, Buitelaar \& Savelkoul [22] have advanced the hypothesis that ADHD may be a non-allergic hypersensitivity disorder, with pathophysiological links to asthma.C

Previous studies that have examined the potential relationship between ADHD and asthma have not presented consistent results. Both a study of 140 boys with ADHD [23] and a study of 140 girls with ADHD [24] failed to find a positive association between ADHD and asthma. However, in a large study from the National Survey of Children's Health in the USA, children with asthma were more likely to have co-morbid ADHD compared

\section{Biomed Central}


with children without asthma [25]. A previous study on adults, with data from a large claims database in the USA, showed that ADHD was significantly associated with asthma [26].

In a study using data from the Norwegian Prescription Database we have shown that patients prescribed drugs to treat ADHD also are prescribed anti-asthma drugs significantly more often than the rest of the population [27].

The aims of the present study were to (1) investigate the prevalence of asthma among clinically diagnosed adults with ADHD, compared to controls from a normal population, and to (2) investigate if the presence of asthma is associated with differences in symptom patterns and demographic variables in patients and controls.

\section{Methods \\ Subjects}

This is a cross-sectional study of 594 Norwegian patients diagnosed with adult ADHD and a comparison group of 719 persons from the general population. The patients were recruited as part of a genetic study using a national registry of adults diagnosed with ADHD in Norway during 1997-May 2005 [11,21,28,29]. The diagnostic assessment of the patients in the registry was made by one of three national expert committees for ADHD, and was based on detailed clinical information (including information from informants) provided by the referring clinicians, mainly psychiatrists. The diagnosis of ADHD was made according to the ICD-10 research criteria, with two modifications; allowing the inattentive subtype, as in DSM-IV, as sufficient for the diagnosis, and allowing for the presence of co-morbid psychiatric disorders, as long as the criteria for ADHD were present before the appearance of the co-morbid disorder.

To enhance recruitment and to include patients diagnosed also later than May 2005, psychiatrists and psychologists nation-wide were invited to recruit formally diagnosed adult patients with ADHD. The inclusion criteria were a diagnosis of ADHD according to the criteria described above, and age above 18 years. There were no formal exclusion criteria. In the present paper we report on data from a total of 594 patients, 340 from the national registry, and 254 from the recruitment performed after May 2005.

The control group was recruited using the database of The Medical Birth Registry of Norway (MBRN). The MBRN includes all people born in Norway after January 1st 1967. Invitation letters were sent out in 2007-2009 to a randomly selected sample of persons between 18-40 years from all over Norway. Data from the first 719 persons recruited are presented in the present report. For further details about the recruitment strategy and the patient sample, see Johansson et al. 2008 [21], Halleland et al. 2009 [28], Halmøy et al. 2009 [11], and Halmøy et al. 2010 [29].

Informed consent based on detailed written information about the project was obtained from all patients and controls. The study was approved by the Regional Research Ethical Committee of Western Norway.

\section{Questionnaires}

The following self-report questionnaires were used in this study: The Wender Utah Rating Scale (WURS), measuring the presence and frequency of childhood ADHD symptoms [30], the Adult ADHD Self Report Scale (ASRS) which measures the presence and frequency of current symptoms of ADHD [31,32], and the Mood Disorder Questionnaire (MDQ), a screening questionnaire for bipolar spectrum disorders (BSD) [33].

The WURS is designed to retrospectively record symptoms and signs of ADHD in childhood. The version of the scale used in this study contains 25 questions, each rated on a 5-point severity scale. The WURS-25 has been validated by several investigators in different countries and populations [34,35].

The ASRS is the World Health Organization's (WHO) rating scale for adult ADHD designed to measure current $\mathrm{ADHD}$ symptoms. It consists of 18 items based on DSM-IV symptoms/criteria for ADHD that are measured on a 5 -point scale $(0=$ never/seldom and $4=$ very often), yielding a possible score range from 0-72. The items 1-9 cover the symptoms of inattention; items 1018 the symptoms of hyperactivity and impulsivity. In this study we used a continuous scoring method [32].

The MDQ is a screening instrument for BSD that has been validated for use in the general population and in psychiatric patient populations [33,36]. The MDQ consists of 15 items. The first 13 questions concern periods of life-time symptoms of mania and hypomania, and the last two ask about co-occurrence of symptoms and ranking of functional impairment caused by the symptoms. A standard MDQ positive score is defined as 7 or more 'yes' on the first 13 items, 'yes' on question 14 (co-occurrence of symptoms) and level ' 3 or more' on question 15 (moderate to severe impairment).

In addition, self-reported data were collected concerning socio-demographic and clinical factors including educational and occupational levels and co-morbid symptoms and problems. A diagnosis of asthma was defined as answering yes to the following question: "Have you ever had asthma?"

\section{Statistical analyses}

Bivariate associations were analysed using chi-square tests, t-tests for independent samples, and logistic 
regression analyses. Multivariable associations between ADHD and asthma were examined using a logistic regression model with asthma as the outcome variable, ADHD main predictor, and possible confounders age, gender, education, anxiety/depression and bipolar disorder. All analyses were performed using the Statistical Package for Social Sciences (SPSS) version 15.0.1.

\section{Results}

Clinical and socio-demographic characteristics of ADHD patients and controls are shown in Table 1. In the control group there was a higher proportion of females than in the patient group (59.4\% vs. $48.3 \%)$, and the mean age was lower (29.6 vs 34.0 years). The level of education was lower in the patient group and the relative number holding an ordinary job was far lower. The proportions of ADHD patients reporting a life-time history of depression and/or anxiety, bipolar disorder and alcohol problems were significantly increased compared to the controls, and scores on all the self report scales for psychiatric symptoms were substantially higher in the ADHD patient group than in the control group. All these differences between ADHD patients and controls were similar for males and females.

A total of 143 of the ADHD patients reported that they had asthma $(24.4 \%)$, compared with $81(11.3 \%)$ of the controls $(\mathrm{OR}=2.53,1.88-3.41, \mathrm{p}<0.001)$. Even after controlling for age, gender, education, anxiety/depression, and bipolar disorder in a logistic regression analysis, the OR only decreased slightly, and retained statistical

Table 1 Clinical and socio-demographic characteristics of patients and controls

\begin{tabular}{llll}
\hline & Patients & Controls & $\mathbf{P}$ \\
\hline & $\mathbf{N}=\mathbf{5 9 4}$ & $\mathbf{N}=\mathbf{7 1 9}$ & \\
\hline Age (mean \pm SD) & $34.0 \pm 10.3$ & $29.6 \pm 6.5$ & $<0.001$ \\
\hline Gender (\% females) & 48.3 & 59.4 & $<0.001$ \\
\hline Educational level (\%) & & & \\
\hline Junior high school & 26.3 & 4.0 & \\
\hline Senior high school & 50.0 & 36.4 & \\
\hline College/university & 23.7 & 59.5 & $<0.001$ \\
\hline Occupational level (\%) & & & $<0.001$ \\
\hline Working & 29.1 & 80.5 & $<0.001$ \\
\hline Self reported co-morbidity (\%) & & & $<0.001$ \\
\hline Depression/anxiety & 68.5 & 16.1 & $<0.001$ \\
\hline Bipolar disorder & 11.2 & 1.4 & $<0.001$ \\
\hline Alcohol problems & 23.1 & 2.1 & $<0.001$ \\
\hline WURS (score \pm SD, range 0-100) & $58.6 \pm 17.9$ & $17.5 \pm 14.0$ & $<0.001$ \\
\hline ASRS (score \pm SD, range 0-72) & $45.5 \pm 12.3$ & $22.9 \pm 10.0$ & \\
\hline MDQ + (\%) & 48.2 & 6.3 & 11.3 \\
\hline Asthma(\%) & 24.4 & & $<001$ \\
\hline
\end{tabular}

significance (Table 2). The frequency of self-reported asthma was slightly, but not significantly, higher for females in the control group compared with male controls $(12.7 \%$ vs. $9.2 \%, \mathrm{OR}=1.43,0.88-2.34$, chi square), but significantly higher among the female ADHD patients compared with the male ADHD patients (30.9\% vs. $18.2 \%, \mathrm{OR}=2.01,1.36-2.95, \mathrm{p}<0.001$, chi square).

Table 3 shows the same clinical and socio-demographic characteristics as in Table 1 but this time contrasting ADHD patients with and without asthma. Levels of educational and occupational activity were similar for patients with and without asthma. More ADHD patients with asthma reported a life-time history of depression and/or anxiety than ADHD patients without asthma. This difference was still significant after controlling for age and gender using logistic regression analysis $(\mathrm{OR}=1.72,1.11-2.69$, $\mathrm{p}=0.016$ ). However, whereas $83.6 \%$ of male ADHD patients with asthma reported a history of depression and/ or anxiety compared with $61.1 \%$ in male ADHD patients without asthma, the corresponding figures for female ADHD patients with and without asthma were $72.7 \%$ and $71.8 \%$ respectively, indicating a potential gender-specific effect, where males with asthma had a relatively higher symptom load. MDQ-score was positive in a larger proportion of ADHD patients with asthma, than in ADHD patients without asthma. The reported levels of ADHD symptoms in childhood (WURS), current ADHD symptoms (ASRS score) and self-reported history of bipolar disorder did not differ between the two groups.

The characteristics of controls with and without asthma are shown in Table 4. Controls with asthma were less likely to be employed compared to controls without asthma. However, when controlling for age and gender in a logistic regression analysis this difference was no longer significant $(\mathrm{OR}=0.57,0.32-1.02)$. As for the ADHD patients, self-reported depression and/or anxiety was more prevalent in the asthma group, and was still significant when controlling for age and gender $(\mathrm{OR}=2.10,1.22-3.60, \mathrm{p}=0.007)$. Controls with asthma had more often been diagnosed with bipolar disorders and a larger percentage scored positively on the MDQ-

Table 2 Results from binary logistic regression analysis

\begin{tabular}{llll}
\hline & OR & Cl & P \\
\hline Unadjusted & 2.54 & $1.89-3.44$ & $<0.001$ \\
\hline Adjusted for: & & & \\
\hline age & 2.75 & $2.02-3.73$ & $<0.001$ \\
\hline+ gender & 2.96 & $2.16-4.03$ & $<0.001$ \\
\hline + education & 2.55 & $1.80-3.62$ & $<0.001$ \\
\hline+ anxiety/depression & 1.91 & $1.29-2.82$ & 0.001 \\
\hline+ bipolar disorder & 1.89 & $1.28-2.80$ & 0.002 \\
\hline
\end{tabular}

Odds ratios (ORs) with $95 \%$ confidence intervals (Cls) for having asthma given a diagnosis of ADHD. 
Table 3 Clinical and socio-demographic characteristics of patients with and without asthma

\begin{tabular}{llll}
\hline & Asthma & Not asthma & $\mathbf{P}$ \\
\hline & $\mathbf{N}=\mathbf{1 4 3}$ & $\mathbf{N}=\mathbf{4 4 1}$ & \\
\hline Age (mean \pm SD) & $33.0 \pm 10.2$ & $34.5 \pm 10.3$ & NS \\
\hline Educational level (\%) & & & \\
\hline Junior high school & 30.5 & 24.8 & \\
\hline Senior high school & 51.6 & 49.6 & \\
\hline College/university & 18.0 & 25.6 & NS \\
\hline Occupational level (\%) & & & \\
\hline Working & 24.8 & 30.5 & NS \\
\hline Self reported co-morbidity (\%) & & & \\
\hline Depression/anxiety & 76.9 & 65.8 & 0.013 \\
\hline Bipolar disorder & 13.3 & 10.6 & NS \\
\hline Alcohol problems & 19.7 & 24.1 & NS \\
\hline WURS (score \pm SD, range 0-100) & $60.8 \pm 17.2$ & $57.9 \pm 18.1$ & NS \\
\hline ASRS (score \pm SD, range 0-72) & $45.6 \pm 11.8$ & $45.4 \pm 12.5$ & NS \\
\hline MDQ + (\%) & 57.8 & 45.3 & 0.013 \\
\hline
\end{tabular}

questionnaire than controls without asthma. However, these differences did not reach statistical significance. Interestingly, even among controls, individuals with asthma reported significantly higher levels of current ADHD symptoms (ASRS score) or childhood symptoms (WURS score) than the group without asthma.

\section{Discussion}

There are three main findings of the present study. The first is that adult patients with ADHD significantly more often reported a history of asthma, compared to a

Table 4 Clinical and socio-demographic characteristics of controls with and without asthma

\begin{tabular}{llll}
\hline & Asthma & Not asthma & $\mathbf{P}$ \\
\hline & $\mathbf{N}=\mathbf{8 1}$ & $\mathbf{N}=\mathbf{6 3 6}$ & \\
\hline Age (mean \pm SD) & $28.5 \pm 6.7$ & $29.8 \pm 6.5$ & NS \\
\hline Educational level (\%) & & & \\
\hline Junior high school & 2.5 & 4.3 & \\
\hline Senior high school & 45.0 & 35.2 & \\
\hline College/university & 52.5 & 60.6 & NS \\
\hline Occupational level (\%) & & & \\
\hline Working & 70.1 & 81.9 & 0.022 \\
\hline Self reported co-morbidity (\%) & & & \\
\hline Depression/anxiety & 27.2 & 14.5 & 0.003 \\
\hline Bipolar disorder & 2.5 & 1.1 & NS \\
\hline Alcohol problems & 4.9 & 1.7 & NS \\
\hline WURS (score \pm SD, range 0-100) & $22.1 \pm 15.6$ & $16.9 \pm 13.7$ & 0.008 \\
\hline ASRS (score \pm SD, range 0-72) & $26.0 \pm 11.0$ & $22.5 \pm 9.8$ & 0.003 \\
\hline MDQ + (\%) & 10.4 & 5.8 & NS \\
\hline
\end{tabular}

control population. The second is that controls with self-reported asthma reported more symptoms of ADHD both in childhood and currently, compared to controls without asthma. Finally, asthma in controls and in male ADHD-patients was associated with selfreported depression and/or anxiety.

The ADHD patients in the present study are very impaired as a group, with a low level of education compared to controls, and less than one third being employed in ordinary work. This is in accordance with previous studies showing a low level of occupational functioning in adult patients with persistent ADHD $[10,11]$. However, we found no indication that ADHD patients with asthma represent a more impaired subgroup of ADHD patients. The level of education, employment status and scores on the ASRS and WURS scales were not significantly different from ADHD patients without asthma. Among the controls there was a difference in employment status for patients with and without asthma, but this difference disappeared when controlling for age and gender.

Females in our control group had a slightly higher prevalence of asthma compared to male controls, but the difference was not statistically significant. Whereas childhood asthma is more common in boys, adult asthma is consistently more prevalent in females [37-39], possibly related to hormonal factors $[40,41]$.

In the previous clinical studies on the relationship between ADHD and asthma where no association was found $[23,24]$, children only were examined. In a study using data from the Norwegian Prescription Database, we showed that patients prescribed drugs to treat ADHD also were prescribed anti-asthma drugs significantly more often than the population at large [27]. In the prescription study we found a weaker relationship between ADHD and asthma in the younger age groups ( $<20$ years), than in the older age groups ( $>20$ years), although the associations were significant across all ages. Those findings, together with results from the current study, the study from the National Survey of Children's Health by Blackman et al. [25], and on adults by Secnik, Swensen \& Lage [26], offer strong support for the existence of a co-morbidity between ADHD and asthma.

Such a co-morbidity may appear counterintuitive. ADHD and asthma are very different disorders. ADHD is a chronic disorder comprising problems with attention and concentration, combined with behavioural symptoms such as hyperactivity/restlessness and impulsivity [2]. Asthma is a chronic inflammatory disorder of the airways, with episodic worsening, and symptoms related to the respiratory system. However, both ADHD and asthma have similar co-morbid patterns with regard to anxiety- and mood disorders. ADHD exhibits 
substantial co-morbidity with generalized anxiety disorder, panic disorder, depressive disorders, and bipolar disorder in adults [9]. Asthma is to a similar degree associated with the same anxiety disorders and with bipolar disorder [42,43]. A large number of the ADHD patients in our sample had co-morbid psychiatric disorders $[11,29]$, and male patients with asthma had a particularly high prevalence of depression and/or anxiety. In the control group asthma was also associated with depression and/or anxiety. It is therefore possible that the association between ADHD and asthma is mediated by these other co-morbid disorders.

Much of the current thinking on the pathophysiology and genetics of ADHD has focused on alterations in dopaminergic systems [21], and there is also substantial evidence that dopaminergic mechanisms are involved in mood disorders $[44,45]$. Dopaminergic systems have not received a similar focus in pathophysiological research on asthma, and are unlikely to explain the cause or pathophysiology of asthma. It is however interesting to note, that dopaminergic receptors are present in sensory nerves in the airways [46], and inhaled dopamine is able to induce bronchodilation during an acute asthma attack [47]. It is therefore possible that changes in dopaminergic systems, or perhaps other signalling mechanisms, could explain part of the associations between ADHD and asthma. Possibly, there could be a subgroup of patients sharing underlying pathophysiological disturbances causing combined symptoms of asthma, ADHD, mood- and anxiety disorders.

Other relevant factors that could help to explain this co-morbidity may be due to risk behaviour associated with ADHD, most notably tobacco smoking. Teenage and adult patients with ADHD have a higher prevalence of smoking in comparison with the general population [48]. It is still a matter of controversy whether active smoking is a cause of asthma, but it is certain to aggravate symptoms among subjects that are prone to asthma before they start smoking [49]. Unfortunately, in the present study, we did not collect information on smoking habits. Another possible etiological factor in relation to tobacco is passive smoking in childhood [50] or prenatal exposure, since children with ADHD presumably have been exposed to this to a larger extent than children without ADHD [51]. Both passive smoking in childhood and prenatal exposure is associated with an increased risk for asthma, both in childhood [52] and among adults [53].

Another possibility is that inflammatory mechanisms may be a common factor for these disorders. Such mechanisms are important in the pathophysiology of asthma [54,55], are may be involved in mood disorders $[56,57]$, and are also postulated to be involved in ADHD [58].
Both ADHD and asthma are associated with obesity. Several studies have indicated a higher than expected prevalence of obesity in ADHD patients [59], and obesity is a risk factor for the development of asthma [60]. In regard to this it is also interesting that obesity leads to a proinflammatory state [60]. Unfortunately we did not collect obesity data in this study (body mass index, waist circumference), so we cannot determine to what extent this may have been a contributing factor.

\section{Strengths and limitations}

Concerning limitations it is evident that we are not studying the whole range of ADHD patients. Not all patients with such problems consult a doctor, and those that are recruited to the present study probably represent a more severely affected group [11]. It is therefore uncertain if the present results are applicable to ADHD patients in general. The ASRS, WURS and MDQ are well-known and widely used auto-questionnaires, and even though they have not been subject to official validations in Norway, validation studies performed in various other populations have found them suitable for use $[11,29]$.

The diagnosis of asthma was made on the basis of "yes-no" answers to a questionnaire. We made no qualification that the diagnosis should have been given by a doctor. In a study from Germany a fairly good agreement was found between answers to such a question compared to a subsequent interview by a physician [42] Furthermore, we think it is probable that in a country such as Norway, with a strongly subsidised health service, people that think they have asthma will also have consulted a doctor for such a condition. Still, it is possible that we may have underestimated the prevalence of asthma, since Toren et al. [61] found that self-reported asthma was biased in relation to disease severity, that subjects with a mild disease were less prone to report their asthma. On the other hand, the prevalence figure from the control group (11.3\%) is in fairly good agreement with epidemiological studies from Norway. In a report based on data from 1998/99 Brogger et al. [37] found a $9.3 \%$ prevalence of asthma in Norwegian adults.

\section{Conclusions}

In conclusion, we have shown that adults patients with persistent ADHD have an increased prevalence of asthma compared to controls from the general population, and that controls with asthma report higher levels of both childhood and current ADHD symptoms. This points to a co-morbidity between these two disorders, possibly related to shared risk factors, pathophysiologies and co-morbidities with mood and anxiety disorders. We suggest that future studies should explore underlying pathophysiological mechanisms that may explain the co-occurrence of ADHD and asthma. 


\section{Acknowledgements}

This study was supported financially by the Research Council of Norway and the Western Norway Regional Health Authority.

\section{Author details}

${ }^{1}$ Department of Clinical Medicine, Section for Psychiatry, University of Bergen, Bergen, Norway. ${ }^{2}$ Division of Psychiatry, Haukeland University Hospital, Bergen, Norway. ${ }^{3}$ K.G. Jebsen Centre for Research on Neuropsychiatric Disorders, Bergen, Norway. ${ }^{4}$ Department of Biomedicine, University of Bergen, Bergen, Norway. ${ }^{5}$ Department of Thoracic Medicine, Haukeland University Hospital, Bergen, Norway. ${ }^{6}$ Institute of Medicine, Section for Thoracic Medicine, University of Bergen, Bergen, Norway.

\section{Authors' contributions}

$\mathrm{JH}, \mathrm{AH}$ and $\mathrm{OBF}$ participated in the design of the study. AH collected and plotted data. OBF performed the statistical analyzes. OBF, JH, TME and KJO drafted the manuscript. All authors contributed to the interpretation of data and revised the manuscript. All authors read and approved the final manuscript.

\section{Competing interests}

During the past three years JH has been invited as a lecturer by JanssenCilag and Novartis, AH by Janssen-Cilag and OBF by Bristol-Meyers Squibb. TME has received an unrestricted grant from AstraZeneca in 2008, and travel support to attend the American Thoracic Society congresses in 2008 and 2011 from GlaxoSmithKline. KJO declare that he has no competing interests.

Received: 22 February 2011 Accepted: 7 August 2011

Published: 7 August 2011

\section{References}

1. Faraone SV, Sergeant J, Gillberg C, Biederman J: The worldwide prevalence of ADHD: is it an American condition? World Psychiatry 2003, 2:104-113.

2. Barkley RA: Attention-deficit hyperactivity disorder. A handbook for diagnosis and treatment New York: The Guilford Press; 2006.

3. Barkley RA, Fischer M, Smallish L, Fletcher K: The persistence of attentiondeficit/hyperactivity disorder into young adulthood as a function of reporting source and definition of disorder. J Abnorm Psychol 2002, 111:279-289.

4. Adler LA, Chua HC: Management of ADHD in adults. J Clin Psychiatry 2002, 63(suppl 12):29-35.

5. Heiervang E, Stormark KM, Lundervold AJ, Heimann M, Goodman R, Posserud MB, Ullebø AK, Plessen K, Bjelland I, Lie SA, Gillberg C: Psychiatric disorders in Norwegian 8- to 10-year-olds: an epidemiological survey of prevalence, risk factors, and service use. J Am Acad Child Adolesc Psychiatry 2007, 46:438-447.

6. Biederman J, Faraone SV: Attention-deficit hyperactivity disorder. Lancet 2005, 366:237-248

7. Polanczyk G, de Lima MS, Horta BL, Biederman J, Rohde LA: The worldwide prevalence of ADHD: a systematic review and metaregression analysis. Am J Psychiatry 2007, 164:942-948.

8. Fayyad J, De Graaf R, Kessler R, Alonso J, Angermeyer M, Demyttenaere K, De Girolamo G, Haro JM, Karam EG, Lara C, Lépine JP, Ormel J, PosadaVilla J, Zaslavsky AM, Jin R: Cross-national prevalence and correlates of adult attention-deficit hyperactivity disorder. Br J Psychiatry 2007. 190:402-409.

9. Kessler RC, Adler L, Barkley R, Biederman J, Conners CK, Demler O, Faraone SV, Greenhill LL, Howes MJ, Secnik K, Spencer T, Ustun TB, Walters EE, Zaslavsky AM: The prevalence and correlates of adult ADHD in the United States: results from the National Comorbidity Survey Replication. Am J Psychiatry 2006, 163:716-723.

10. Kessler RC, Adler LA, Barkley R, Biederman J, Conners CK, Faraone SV, Greenhill LL, Jaeger S, Secnik K, Spencer T, Ustün TB, Zaslavsky AM: Patterns and predictors of attention-deficit/hyperactivity disorder persistence into adulthood: results from the national comorbidity survey replication. Biol Psychiatry 2005, 57:1442-1451.

11. Halmøy A, Fasmer OB, Gillberg C, Haavik J: Occupational Outcome in Adult ADHD: Impact of symptom profile, co-morbid psychiatric problems and treatment: a cross-sectional study of 414 clinically diagnosed adult ADHD patients. J Atten Disord 2009, 13:75-87.
12. Apter AJ, Szefler SJ: Advances in adult and pediatric asthma. J Allergy Clin Immunol 2006, 117:512-8.

13. Eagan TM, Bakke PS, Eide GE, Gulsvik A: Incidence of asthma and respiratory symptoms by sex, age and smoking in a community study. Eur Respir J 2002, 19:599-605.

14. Rees J: ABC of asthma. Prevalence. BMJ 2005, 331:443-5.

15. Meyers DA: Genetics of asthma and allergy: what have we learned? J Allergy Clin Immunol 2010, 126:439-46.

16. Franke B, Neale BM, Faraone SV: Genome-wide association studies in ADHD. Hum Genet 2009, 126:13-50.

17. McQuaid EL, Kopel SJ, Nassau JH: Behavioral adjustment in children with asthma: a meta-analysis. Journal of Developmental \& Behavioral Pediatrics 2001, 22:430-439.

18. Goodwin RD, Jacobi F, Thefeld W: Mental disorders and asthma in the community. Arch Gen Psychiatry 2003, 60:1125-1130.

19. Katon W, Lozano P, Russo J, McCauley E, Richardson L, Bush T: The prevalence of DSM-IV anxiety and depressive disorders in youth with asthma compared to controls. J Adolesc Health 2007, 41:455-463.

20. Di Marco F, Santus P, Centanni S: Anxiety and depression in asthma. Curr Opin Pulm Med 2011, 17:39-44.

21. Johansson S, Halleland H, Halmøy A, Jacobsen K, Landaas E, Dramsdahl M, Fasmer OB, Bergsholm P, Lundervold AJ, Gillberg C, Hugdahl K, Knappskog PM, Haavik J: Genetic analyses of dopamine related genes in adult ADHD patients suggest an association with the DRD5microsatellite repeat, but not with DRD4 or SLC6A3 VNTRs. Am J Med Genet B Neuropsychiatr Genet 2008, 147B:1470-1475.

22. Pelsser LM, Buitelaar JK, Savelkoul HF: ADHD as a (non) allergic hypersensitivity disorder: A hypothesis. Pediatr Allergy Immunol 2009 20:107-112.

23. Biederman J, Milberger S, Faraone SV, Guite J, Warburton R: Association between childhood asthma and ADHD: issues of psychiatric comorbidity and familiality. J Am Acad Child Adolesc Psychiatry 1994, 33:842-848.

24. Hammerness P, Monuteaux MC, Faraone SV, Gallo L, Murphy H, Biederman J: Reexamining the familial association between asthma and ADHD in girls. J Atten Disord 2005, 8:136-143.

25. Blackman JA, Gurka MJ: Developmental and behavioral comorbidities of asthma in children. Journal of Developmental \& Behavioral Pediatrics 2007, 28:92-99.

26. Secnik K, Swensen A, Lage MJ: Comorbidities and costs of adult patients diagnosed with attention-deficit hyperactivity disorder. Pharmacoeconomics 2005, 23:93-102.

27. Fasmer OB, Riise T, Eagan TM, Lund A, Dilsaver SC, Hundal $\varnothing$, Oedegaard KJ: Comorbidity of asthma with ADHD. J Atten Disord 2011.

28. Halleland H, Lundervold A, Halmøy A, Johansson S, Haavik J: Association between Catechol O-methyltransferase (COMT) haplotypes and severity of hyperactivity symptoms in adults. Am J Med Genet B Neuropsychiatr Genet 2009 , 150B:403-410.

29. Halmøy A, Halleland H, Dramsdahl M, Bergsholm P, Haavik J: Bipolar symptoms in adult attention deficit hyperactivity disorder: A crosssectional study of 510 clinically diagnosed patients and 417 populationbased controls. J Clin Psychiatry 2 2010, 71:48-57.

30. Ward MF, Wender PH, Reimherr FW: The Wender Utah Rating Scale: an aid in the retrospective diagnosis of childhood attention deficit hyperactivity disorder. Am J Psychiatry 1993, 150:885-890.

31. Adler LA, Spencer T, Faraone SV, Kessler RC, Howes MJ, Biederman J, Secnik K: Validity of pilot adult ADHD self-report scale (ASRS) to rate adult ADHD symptoms. Ann Clin Psychiatry 2006, 18:145-148.

32. Kessler RC, Adler L, Ames M, Demler O, Faraone S, Hiripi E, Howes MJ, Jin R, Secnik K, Spencer T, Ustun TB, Walters EE: The World Health Organization Adult ADHD Self-Report Scale (ASRS): a short screening scale for use in the general population. Psychol Med 2005, 35:245-256.

33. Hirschfeld RM, Williams JB, Spitzer RL, Calabrese JR, Flynn L, Keck PE Jr Lewis L, McElroy SL, Post RM, Rapport DJ, Russell JM, Sachs GS, Zajecka J: Development and validation of a screening instrument for bipolar spectrum disorder: the Mood Disorder Questionnaire. Am J Psychiatry 2000, 157:1873-1875

34. Fossati A, Di Ceglie A, Acquarini E, Donati D, Donini M, Novella L, Maffei C: The retrospective assessment of childhood attention deficit hyperactivity disorder in adults: reliability and validity of the Italian version of the Wender Utah Rating Scale. Compr Psychiatry 2001. 42:326-336. 
35. Rodriguez-Jimenez R, Ponce G, Monasor R, Jiménez-Giménez M, PérezRojo JA, Rubio G, Jiménez Arriero, Palomo T: [Validation in the adult Spanish population of the Wender Utah Rating Scale for the retrospective evaluation in adults of attention deficit/hyperactivity disorder in childhood]. Rev Neurol 2001, 33:138-144.

36. Hirschfeld RM, Holzer C, Calabrese JR, Weissman M, Reed M, Davies M, Frye MA, Keck P, McElroy S, Lewis L, Tierce J, Wagner KD, Hazard E: Validity of the mood disorder questionnaire: a general population study. Am J Psychiatry 2003, 160:178-180.

37. Brogger J, Bakke P, Eide GE, Johansen B, Andersen A, Gulsvik A: Long-term changes in adult asthma prevalence. Eur Respir J 2003, 21:468-472.

38. Vink NM, Postma DS, Schouten JP, Rosmalen JG, Boezen HM: Gender differences in asthma development and remission during transition through puberty: the TRacking Adolescents' Individual Lives Survey (TRAILS) study. J Allergy Clin Immunol 2010, 126:498-504, e1-6.

39. Tollefsen E, Bjermer L, Langhammer A, Johnsen R, Holmen TL: Adolescent respiratory symptoms-girls are at risk: the Young-HUNT study, Norway. Respir Med 2006, 100:471-476.

40. Balzano G, Fuschillo S, Melillo G, Bonini S: Asthma and sex hormones. Allergy. 2001, 56:13-20

41. Macsali F, Real FG, Plana E, Sunyer J, Anto J, Dratva J, Janson C, Jarvis D, Omenaas ER, Zemp E, Wjst M, Leynaert B, Svanes C: Early Age of Menarche, Lung Function and Adult Asthma. Am J Respir Crit Care Med 2011, 183:8-14.

42. Goodwin RD, Jacobi F, Thefeld W: Mental disorders and asthma in the community. Arch Gen Psychiatry 2003, 60:1125-1130.

43. Hasler G, Gergen PJ, Kleinbaum DG, Ajdacic V, Gamma A, Eich D, Rössler W, Angst J: Asthma and panic in young adults: a 20-year prospective community study. Am J Respir Crit Care Med 2005, 171:1224-1230.

44. Emilien G, Maloteauw J-M, Geurts M, Hoogenberg K, Cragg S: Dopamine receptors-physiological understanding to therapeutic intervention potential. Pharmacol Ther 1999, 84:133-56.

45. Dunlop BW, Nemeroff CB: The role of dopamine in the pathophysiology of depression. Arch Gen Psychiatry 2007, 64:327-337.

46. Birrell MA, Crispino N, Hele DJ, Patel HJ, Yacoub MH, Barnes PJ, Belvisi MG: Effect of dopamine receptor agonists on sensory nerve activity: possible therapeutic targets for the treatment of asthma and COPD. $\mathrm{Br} J$ Pharmacol 2002, 136:620-628.

47. Cabezas GA, Lezama Y, Velasco M: Dopaminergic modulation of human bronchial tone. Arch Med Res 2001, 32:143-147.

48. McClernon FJ, Kollins SH: ADHD and smoking: from genes to brain to behavior. Ann N Y Acad Sci 2008, 1141:131-147.

49. Thomson NC, Chaudhuri R, Livingston E: Asthma and cigarette smoking. Eur Resp J 2004, 24:822-833.

50. Stoddard JJ, Gray B: Maternal smoking and medical expenditures for childhood respiratory illness. Am J Public Health 1997, 87:205-209.

51. Braun JM, Kahn RS, Froehlich T, Auinger P, Lanphear BP: Exposures to environmental toxicants and attention deficit hyperactivity disorder in U.S. children. Environ Health Perspect 2006, 114:1904-1909.

52. Cook DG, Strachan DP: Health effects of passive smoking-10: Summary of effects of parental smoking on the respiratory health of children and implications for research. Thorax 1999, 54:357-366.

53. Skorge TD, Eagan TM, Eide GE, Gulsvik A, Bakke PS: The adult incidence of asthma and respiratory symptoms by passive smoking in uterus or in childhood. Am J Respir Crit Care Med 2005, 172:61-66.

54. Barrios RJ, Kheradmand F, Batts L, Corry DB: Asthma: pathology and pathophysiology. Arch Pathol Lab Med 2006, 130:447-451.

55. Bousquet J, Jeffery PK, Busse WW, Johnson M, Vignola AM: Asthma. From bronchoconstriction to airways inflammation and remodelling. Am J Respir Crit Care Med 2000, 161:1720-1745.

56. Bremmer MA, Beekman AT, Deeg DJ, Penninx BW, Dik MG, Hack CE, Hoogendijk WJ: Inflammatory markers in late-life depression: results from a population-based study. J Affect Disord 2008, 106:249-255.

57. Dickerson F, Stallings C, Origoni A, Boronow J, Yolken R: Elevated serum levels of $C$-reactive protein are associated with mania symptoms in outpatients with bipolar disorder. Prog Neuropsychopharmacol Biol Psychiatry 2007, 31:952-955.

58. Bazar KA, Yun AJ, Lee PY, Daniel SM, Doux JD: Obesity and ADHD may represent different manifestations of a common environmental oversampling syndrome: a model for revealing mechanistic overlap among cognitive, metabolic, and inflammatory disorders. Med Hypotheses 2006, 66:263-269.

59. Cortese $S$, Angriman $M$, Maffeis $C$, Isnard $P$, Konofal $E$, Lecendreux $M$, Purper-Ouakil D, Vincenzi B, Bernardina BD, Mouren MC: Attention-deficit/ hyperactivity disorder (ADHD) and obesity: a systematic review of the literature. Crit Rev Food Sci Nutr 2008, 48:524-537.

60. Delgado J, Barranco P, Quirce S: Obesity and asthma. J Investig Allergol Clin Immunol 2008, 18:420-425.

61. Torén K, Brisman J, Järvholm B: Asthma and asthma-like symptoms in adults assessed by questionnaires. A literature review. Chest 1993, 104:600-608

\section{Pre-publication history}

The pre-publication history for this paper can be accessed here: http://www.biomedcentral.com/1471-244X/11/128/prepub

doi:10.1186/1471-244X-11-128

Cite this article as: Fasmer et al:: Adult attention deficit hyperactivity disorder is associated with asthma. BMC Psychiatry 2011 11:128.

\section{Submit your next manuscript to BioMed Central and take full advantage of:}

- Convenient online submission

- Thorough peer review

- No space constraints or color figure charges

- Immediate publication on acceptance

- Inclusion in PubMed, CAS, Scopus and Google Scholar

- Research which is freely available for redistribution

Submit your manuscript at www.biomedcentral.com/submit
C) Biomed Central 